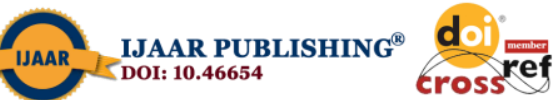

International Journal of Advanced Academic Research (Arts, Humanities and Education) | ISSN: 2488-9849

Vol. 5, Issue 8 (August, 2019) | www.ijaar.org

Journal DOI: $10.46654 /$ ij. 24889849

Article DOI: $10.46654 / \mathrm{ij} .24889849 . \mathrm{a} 580116$

\title{
ISLAMIC RELIGIOUS LEADERS AND CITIZEN ENGAGEMENT FOR GOOD GOVERNANCE IN NIGERIA: SHEIK GUMI'S IDEA AS A CASE IN POINT
}

\author{
YUSUF, Muibi Gbolagade \\ Department of Islamic Studies, \\ School of Secondary Education (Arts \& Social Sciences), \\ The College of Education, Lanlate, \\ Oyo State, Nigeria.
}

\begin{abstract}
This paper examines the role of Islamic religious leaders in the promotion of good governance in Nigeria as exemplified by Sheik Gumi's idea. The study is descriptive in nature using correlation analytical method with self-designed questionnaire as data collection instrument. Chi-square method at 5\% level of significance was used to determine rejection or otherwise of the null hypotheses. Findings reveal that religious leaders do have significant role to play in mobilising their followers for citizen engagement for the attainment of good democratic governance. Also, it was revealed that ethical virtues of both Islamic religious leaders and their followers is a sine qua non for the actualisation of citizen engagement for the enthronement of democratic good governance. Based on the findings, it was suggested that religious leaders and their followers should not be found wanting in demonstrating virtuous attitudes like honesty and love of others for them to be able to serve as vanguard that checks the corrupt attitudes of Nigerian political leaders, among others.
\end{abstract}

Keywords: Islam, good governance, religious leaders and citizen engagement. 


\section{Introduction}

Societies struggle to become democratic, because as a system of government, democracy is taken to be better than dictatorship in terms of being responsive to the interests and needs of the greatest number of citizens. It has been averred that there exists a definite correlation between the hitherto lack of democracy in African politics and the deterioration of socio-economic conditions on the continent. Then, democracy was advocated as a remedy because its inbuilt accountability can lead to more responsible use of public resources and hence, high levels of development (Ayang' Nyongo, 1988). Thus, democracy is seen as a system of government that yields dividend for the citizens. The term dividend of democracy connotes the provision of democratic good governance: fundamental human rights, the rule of law and most importantly, social amenities such as good road network, portable water, wellequipped medical facilities, affordable education etc. It generally connotes the improvement of people's standard of living through improved education, income, skill development and employment, reliable power supply, quality health services, proper sanitation, affordable housing and security of life and property (Waziri, 2009; Adeleke \& Solaru, 2018; Mailafia, 2019 \& Adegboruwa, 2019). Dividend of democracy is basically democratic good governance. In Nigeria, however, the reverse has been the case. What obtains is that poverty has been a problem plaguing Nigeria right from pre-independence to the present time. The poverty index of Nigerians is never encouraging, and this is a hallmark of the parlous state of development of the country. Nigeria has become a state where you are forced to generate your own electricity, provide your own water, build your own road, employ your own security, provide yourself healthcare for you to live etc. (Adegboruwa, 2019).

Poverty that plagues Nigeria is not as a result of scarcity of socio-economic resources, but the attitudes of politicians that corruptly transfer the resources to the private use. In this wise, democracy is too costly to be left to the hands of politicians. Thus, religious leaders, as a segment of the civil society must be ready to mobilise their followers for engagement to make democracy serve the purpose for which it was adopted in the first instance. Given the above scenario, this paper is set to bring into light the following issues: the role of democracy in the development of the citizens; the current grotesque picture of governance in Nigeria; what roles are expected of religious leaders to move for change using Sheik Gumi as an example in Islam; what factors can inhibit religious leaders from acting for mobilisation for citizen engagement, and lastly what can be done to make religious leaders to be active in citizen engagement.

\section{DEFINITIONAL ISSUES}

\section{Democracy}

Historically, democracy has its origin traceable to the ancient Greek States. The Athenian leader, Cleisthenes introduced "an orderly and amazingly rapid sequence of reforms" which led to the rise of a political system called demokratia or "rule by the people" in the year 507 B. C. This system is comprised of three separate institutions: the ekklesia, a sovereign governing body that wrote laws and dictated foreign policy; the boule, a council of representatives from the 10 Athenian tribes; and the dikasteria, the popular courts in which citizens argued cases before a group of lottery-selected jurors. Although the Athenian democracy survived for just two centuries, Cleisteines' invention remains one of the most 
enduring legacies of the ancient Greece to the modern world (Jega, 2007 \& Adegboruwa, 2019).

The simplest definition of democracy has been offered by President Abraham Lincoln in his Gettysburg address on 19 November, 1863, during the American civil war, that "this nation under God shall have a new birth of freedom and that government of the people, by the people for the people shall not perish from earth". This implies that no matter how popular or benevolent a military regime may be, it is still a dictatorship and that democracy has gone by the board when a group of officers seizes the government, pushes the constitution aside, and abolishes or suspends political parties and elections (Ojo, 2009). According to Robert Dahl (1998, cited in Ojo, 2009), for democracy to reign in any country or society, the following are the necessary concomitants: effective participation, equality in voting, gaining enlightened understanding of exercising final control over the agenda and inclusion of adults and that such democracy is likely to produce the following desirable consequences (a) avoiding tyranny (b) upholding essential rights (c) sustaining a feeling of general freedom (d) self determination (e) and the moral autonomy of individual citizens.

\section{Good Governance}

This is the existence of efficient and accountable institutions, namely political, judicial, administrative, economic, corporate and entrenched rules that promote development, protect human rights, respect the rule of law, ensure that people are free to participate in, and be heard in decisions that affect their lives". The goal of good governance is building a capable state, which is "the one that effectively fulfils its obligations to its constituents by providing and satisfying a range of goods both tangible and intangible, that ensures its people of a secure public space wherein they can live and love, produce and reproduce and pursue the enjoyment of the fruits of their labour and love. Such a state will have attributes such as territorial integrity, public order and safety, rule of law, ample public space for individual and group self-realization, and socio-economic justice and equity that minimizes conflict and foster intra-national peace and harmony" (Obianyo, 2009).

\section{Religious Leaders}

Whatever the size of the collectivity, leadership plays crucial roles in the society and these include, according to Adei (2007, cited in Okoye, 2013), the following:

- The provision of direction, including a national mission, vision, and goals, that is, a development agenda.

- The setting of strategy.

- The empowerment of people; and the mobilization and application of resources (human, natural, financial etc).

- The management of the development process

- The establishment of the governance framework and an atmosphere for other actors to operate.

- The development of other leaders, institutions, and general capacity building. Individuals who get themselves involved in the above on religious organisations are hereby taken as religious leaders. 


\section{Mobilisation}

From the perspective of the Directorate of Mass Mobilisation for Self-Reliance, Economic Recovery and Social Justice (MAMSER), mobilisation could be described as the process of pooling together, harnessing, actualising and utilising potential human resource for the purpose of development. It is a process whereby human beings are made aware of the resources at their disposal, and are also motivated and energised to collectively utilise such resources for the improvement of their spiritual and material conditions of living (Gana, 1987, cited in Odumosu, 1992). In the words of Obasi (1983, cited in Ogundiya, 2009), mobilisation refers to the process whereby a concerted effort is made to engage the full attention of the members of the society and channel their energies in a systematic manner for the achievement of certain goals. Mobilisation could take different forms; economic, political religious, military and ethnic (Osagahe, 1988, cited in Ogundiya, 2009).

\section{Analytical School}

\section{The Doctrine of Perpetual Revolution}

Mao Zedong (1892-1976) points out that the class struggle does not end with establishment of a communist state, it only takes new forms. To him, contradictions continue under communism between the progress and conservatism, between advanced and the backward, between the positive and negative, even between the productive forces and the conditions of production. They must then be fought perpetually in order to achieve the goal of communism. Revolution is therefore a perpetual and a continuous process. This view is described as the "the doctrine of perpetual revolution" (Gauba, 2007). This doctrine is also applicable to democratic struggles in developing countries like Nigeria. The significance is that democracy should not be left to the political class; the masses must continuously engage the state to remove all elements of conservatism, backwardness, negativity, oppression that hinder the masses from benefiting from democracy socio-economically. Periodic elections do not imply that the citizens are a beneficiary of democracy since "free election of masters does not abolish the masters or the slaves... what obtains in these societies is a comfortable, smooth democratic unfreedom" (Herbert Mercuse, 1964 quoted in Jinadu, 1979). Thus, democracy is a continuous struggle (Diamond, 2009).

\section{Islamic Religious Leaders and Citizens Engagement in Nigeria: The Case of Sheik Gumi}

Political leaders especially in Africa are not ready to cater for the interest of all the citizens, but democratic system is subsumed to be opposite. They exhibit authoritarianism. Ake (cited in Emenuo, 2015) recognised four ways by which political authoritarianism undermined development in Africa. First, political repression has turned politics into 'warfare', thereby infecting leaders with 'siege mentality' and effectively relegating development issues to very 'low priorities'. Two, the reliance on repression by leaders, has 'disconnected' them from their people and 'completely dissociated' public policy from social needs. Thirdly, constant coercion of the people has alienated them from the state which is therefore seen as a force to be 'feared, evade, cheated and defeated as circumstances permit'. Fourthly, it has occasioned an enormous waste of human resources, the very engine of development. These problems can be resolved through democracy because democratic institutions are said to have the capability and processes that bolster the dimensions of rights, equality and accountability (Adegboyega, 2019). 
This cannot be attained without citizen engagement. Consequently, Pat Merloe (quoted in Adegboruwa, 2019) has reasoned that "There is no democracy without the engagement of citizens. Engagement is thus both a right and responsibility of citizens in establishing, developing and sustaining democracy. Citizen engagement is not an abstraction; it takes tangible forms and serves particular purposes to improve people's lives. Citizen engagement pursues economic, social, cultural and political development, including the provision of opportunity, resources, services, and security".

Sheik Gumi during his life time was an embodiment of citizen engagement especially for the Muslims. He enjoined Muslims to involve themselves and participate actively in governmental, educational and economic activities with a view to enhancing the presence and influence of Islam in the public place. He contended that to vote for a right candidate is to wage jihad (struggle) for the sake of Allah. He consistently argued that politics and political power are more important to the generality of Muslims than obligatory prayer (salah). He kept on with this stand despite the controversy surrounding it (Mohammad, 2009). Right in the Quran, Muslims are directed to make trust to those who are worthy of them (Quran 4:9). The prophetic Hadith also canvassed for election of good leaders as a way of correcting evils in the society. The Hadith appears thus:

Whosoever from among you should see any evil being committed; he should stop it with his hand, and if he is unable to do so, then he should stop it with his tongue. And if he is unable to do so, then he should stop it with his heart. And this (later) is the weakest degree of faith.

It is against this that Jega (1997) cited in Mohammad (2009) reasoned that the reasoning and force behind such argument can be seen in the sense that political power is a factor of the highest potency in the complete and comprehensive replacement of the prevailing economic, political, social, legal, administrative and cultural structures with those based on Islamic values. Therefore, religion plays important role in social change. According to Mohammad (2009):

A religious movement which keeps aloof from politics and enjoins its members to refrain from participation in politics can hardly possess the capacity to force radical changes in the policy content and in the nature of political authority.

\section{Statement of the Problem}

Human beings by nature are selfish and egoistic, and as such religious leaders as a platform for citizen engagement for democratic good governance may be hampered. Most religious leaders do not possess ethical standards especially Socratic principle, which is seeking to be a man before being a citizen, or a pastor, because a pastor who is not a man is a tragedy. Socratic principle seeks the pursuit of truth and excellence imposing the necessary discipline, and drawing moral and ethical boundaries. Elements of Socratic principles are virtues of honesty, diligence, and respects for the rights of others, as national virtues essential for development. Thus, it makes one recognize the truth, seek for excellence and not compromise for less (Ajayi, 1999). It makes one live for others and self, and not self only which breeds excessive desire for materialism, and thus the development of the society generally. So, when civil society challenges the government from time to time, government yields to the needs and interests of the citizens, bad governance is reduced. Given the above, the following hypotheses are raised for testing. 


\section{METHODOLGY}

This study is descriptive in nature, using correlation analysis with the inhabitants of Oyo State forming the population of the study. A total of 150 male and female respondents from Ibarapa Zone of Oyo State were randomly selected. These include Muslims who are civil servants and students of tertiary institutions in the area. A 15 item interview guide was used as the study information sourcing instrument. The distribution of the instrument goes thus: Ibarapa West local government area (50); Ibarapa East local government area (50); and Ibarapa Central local government area (50). The questionnaire was based on 4- Likert scale of Strongly Agreed (SA), Agreed (A), Strongly Disagreed (SD) and Disagreed (D). The draft instrument was validated by experienced senior academic staff before it was administered.

\section{Hypotheses}

Ho1: There is no significant relationship between democracy and good governance.

Ho2: Religious leaders do not have any role to play in mobilizing the followers for citizen engagement for democratic good governance.

Ho3: The ethical virtues of Islamic religious leaders and their followers do not influence the mobilizing role of religious leaders for citizen engagement.

\section{Results and Discussion of findings}

Hypothesis 1: The relationship between democracy and good governance in Nigeria

\begin{tabular}{|c|c|c|c|c|c|c|}
\hline \multirow[t]{2}{*}{$\mathbf{S} / \mathbf{N}$} & \multirow[t]{2}{*}{ ITEMS } & \multirow[t]{2}{*}{ NO. } & \multicolumn{4}{|c|}{ RESPONSES } \\
\hline & & & SA & $\mathbf{A}$ & D & SD \\
\hline 1. & $\begin{array}{l}\text { Democracy is truly the } \\
\text { government of the people, by } \\
\text { the people and for the people. }\end{array}$ & \multirow{5}{*}{150} & 40 & 80 & 15 & 15 \\
\hline 2. & $\begin{array}{l}\text { Democracy is a promoter of } \\
\text { the ideals of equality, } \\
\text { inalienable rights of citizens } \\
\text { and majority rule in the } \\
\text { political community }\end{array}$ & & 70 & 32 & 26 & 22 \\
\hline 3. & $\begin{array}{l}\text { Democracy is instrumental to } \\
\text { the poverty and empowerment } \\
\text { of the citizens. }\end{array}$ & & 47 & 60 & 20 & 23 \\
\hline 4. & $\begin{array}{l}\text { Practising democracy in plural } \\
\text { societies like Nigeria can help } \\
\text { promote national unity and } \\
\text { human happiness. }\end{array}$ & & 85 & 40 & 16 & 09 \\
\hline 5. & $\begin{array}{l}\text { The security and welfare of } \\
\text { the people should be the } \\
\text { priority of having democratic } \\
\text { government in the society. }\end{array}$ & & 48 & 50 & 30 & 22 \\
\hline
\end{tabular}


Result of Chi-square statistics for hypothesis 1

\begin{tabular}{|l|l|l|l|l|l|}
\hline $\begin{array}{l}\text { No of rows } \\
(\mathrm{r})\end{array}$ & $\begin{array}{l}\text { No of of } \\
\text { columns (c) }\end{array}$ & $\begin{array}{l}\text { Degree } \\
\text { freedom (r-1) } \\
\text { (c- }\end{array}$ & $\mathrm{X}^{2}$ cal & $\begin{array}{l}\mathrm{X}^{2} \\
\text { tab }\end{array}$ & Decision \\
\hline 5 & 2 & 4 & 18.55 & 9.49 & $\begin{array}{l}\mathrm{Ho}_{1} \text { is not } \\
\text { accepted }\end{array}$ \\
\hline
\end{tabular}

Since $\mathrm{X}^{2}$ cal $(18.55)>\mathrm{X}^{2}$ tab (9.49) at 5\% level of significance, the null hypothesis is rejected and the alternative hypothesis which states that there is a relationship between democracy and good governance is upheld. This corroborates Ake's view (cited in Emenuo, 2015) that democracy has some value in the political community.

Hypothesis 2: Religious leaders and mobilizing their followers for citizen engagement for democratic good governance

\begin{tabular}{|c|c|c|c|c|c|c|}
\hline \multirow[t]{2}{*}{$\mathbf{S} / \mathbf{N}$} & \multirow[t]{2}{*}{ ITEMS } & \multirow[t]{2}{*}{ NO. } & \multicolumn{4}{|c|}{ RESPONSES } \\
\hline & & & SA & $\mathbf{A}$ & D & SD \\
\hline 1. & $\begin{array}{l}\text { Religious leaders are a vital part } \\
\text { of the civil society and an engine } \\
\text { of change. }\end{array}$ & & 92 & 20 & 20 & 10 \\
\hline 2. & $\begin{array}{l}\text { Religion is significant in Nigeria } \\
\text { as most Nigerians are religiously } \\
\text { inclined. }\end{array}$ & & 102 & 37 & $\mathbf{0 3}$ & $\overline{08}$ \\
\hline 3. & $\begin{array}{l}\text { Most religious leaders don't } \\
\text { inculcate the habit of engaging in } \\
\text { politics in their followers. }\end{array}$ & 150 & 48 & 40 & 33 & 29 \\
\hline 4. & $\begin{array}{l}\text { The gullibility of the masses } \\
\text { especially religious followers } \\
\text { makes it essential for religious } \\
\text { leaders to get involved in } \\
\text { mobilisation of their followers } \\
\text { for citizen engagement. }\end{array}$ & & 45 & 43 & 25 & 37 \\
\hline 5. & $\begin{array}{l}\text { Religious leaders } \\
\text { mobilisation of their followers } \\
\text { for citizen engagement makes } \\
\text { politicians to be bold in } \\
\text { corruption. }\end{array}$ & & 96 & 24 & 18 & 12 \\
\hline
\end{tabular}

Result of Chi-square statistics for hypothesis 2

\begin{tabular}{|l|l|l|l|l|l|}
\hline $\begin{array}{l}\text { No of rows } \\
(\mathrm{r})\end{array}$ & $\begin{array}{l}\text { No o of } \\
\text { columns (c) }\end{array}$ & $\begin{array}{l}\text { Degree } \\
\text { freedom (r-1) } \\
1)\end{array}$ & $\begin{array}{l}\mathrm{X}^{2} \\
\mathrm{cal}\end{array}$ & $\begin{array}{l}\mathrm{X}^{2} \\
\text { tab }\end{array}$ & Decision \\
\hline 5 & 2 & 4 & 87.65 & 9.49 & $\begin{array}{l}\mathrm{Ho}_{1} \text { is not } \\
\text { accepted }\end{array}$ \\
\hline
\end{tabular}

Since $X^{2}$ cal $(87.65)>X^{2}$ tab (9.49) at 5\% level of significance, the null hypothesis is rejected and the alternative hypothesis which states that religious leaders do have significant role to play in mobilizing the followers for citizen engagement for 
democratic good governance is upheld. This confirms to Mohammad (2009) that religious movement which keeps aloof from politics and enjoins its members to refrain from participation in politics can hardly possess the capacity to force radical changes in the policy content and in the nature of political authority.

Hypothesis 3: The ethical virtues of religious leaders and their followers and the mobilizing role of religious leaders for citizen engagement.

\begin{tabular}{|c|c|c|c|c|c|c|}
\hline \multirow[t]{2}{*}{$\mathbf{S} / \mathbf{N}$} & \multirow[t]{2}{*}{ ITEMS } & \multirow[t]{2}{*}{ NO } & \multicolumn{4}{|c|}{ RESPONSES } \\
\hline & & & SA & $\mathbf{A}$ & & SD \\
\hline 1. & $\begin{array}{l}\text { No amount of religious sermons can } \\
\text { create the good change of improved } \\
\text { security and welfare of the citizens if the } \\
\text { political class fails to imbibe the ideals of } \\
\text { democracy in decision making. }\end{array}$ & \multirow{5}{*}{150} & 80 & 35 & 14 & 21 \\
\hline 2. & $\begin{array}{l}\text { Religious leaders need to be ethically } \\
\text { upright to be effective in mobilising their } \\
\text { followers for citizen engagement for better } \\
\text { governance in Nigeria. }\end{array}$ & & 90 & 47 & 08 & 05 \\
\hline 3. & $\begin{array}{l}\text { Unethical vices like greed and selfishness } \\
\text { of religious leaders cannot bring } \\
\text { improvement on their own change for } \\
\text { good if not if not triggered by the citizens. }\end{array}$ & & 89 & 46 & 08 & 07 \\
\hline 4. & $\begin{array}{l}\text { Involvement of the citizens in socio- } \\
\text { political change is a key to making the } \\
\text { political class promote good governance } \\
\text { in Nigeria. }\end{array}$ & & 51 & 40 & 29 & 30 \\
\hline 5. & $\begin{array}{l}\text { The citizens must themselves be } \\
\text { committed to the ideals of democracy and } \\
\text { be ethical before they can be mobilised by } \\
\text { religious leaders for citizen engagement. }\end{array}$ & & 38 & 46 & 30 & 36 \\
\hline
\end{tabular}

Result of Chi-square statistics for hypothesis 2

\begin{tabular}{|l|l|l|l|l|l|}
\hline $\begin{array}{l}\text { No of rows } \\
(\mathrm{r})\end{array}$ & $\begin{array}{l}\text { No of of } \\
\text { columns (c) }\end{array}$ & $\begin{array}{l}\text { Degree } \\
\text { freedom (r-1) } \\
1)\end{array}$ & $\mathrm{X}^{2}$ cal & $\begin{array}{l}\mathrm{X}^{2} \\
\text { tab }\end{array}$ & Decision \\
\hline 5 & 2 & 4 & 87.65 & 9.49 & $\begin{array}{l}\mathrm{Ho}_{1} \text { is not } \\
\text { accepted }\end{array}$ \\
\hline
\end{tabular}

Since $X^{2}$ cal $(87.65)>X^{2}$ tab (9.49) at 5\% level of significance, the null hypothesis which states that the ethical virtues of religious leaders and their followers do not influence the mobilizing role of religious leaders for citizen engagement is rejected and the alternative hypothesis is upheld. This is in tandem with Pat Merloe (quoted in Adegboruwa, 2019) that "There is no democracy without the engagement of citizens. Engagement is thus both a right and responsibility of citizens in establishing, developing and sustaining democracy. Citizen engagement is not an abstraction; it takes tangible forms and serves particular purposes to improve people's lives. Citizen engagement pursues economic, social, cultural and political development, including the provision of opportunity, resources, services, and security”. 


\section{Conclusion and Recommendation}

In Nigeria it is palpable that the citizens have not adequately benefited much dividends of democracy going by the spread and intensity of poverty across the length and breadth of Nigeria. This showcases that the hope of the citizens on democracy as a promoter of good governance becomes dashed. The desire for good change is therefore a perpetual and a continuous process. This view is described as the "the doctrine of perpetual revolution" by Mao Zedong (1892-1976) (Gauba, 2007). This doctrine is also applicable to democratic struggles in developing countries like Nigeria and also places the role of religious leaders in citizen engagement for good governance in right perspective. This is the orientation that Sheik Gumi promoted when he was alive, and which is expected of living Islamic religious leaders. Significantly, democracy should not be left to the political class and that the masses must continuously engage the state to remove all elements of conservatism, backwardness, negativity, oppression that hinder the masses from benefiting from democracy socioeconomically. The following suggestions are therefore provided for religious leaders to be effective tool in mobilising the citizens for citizen engagement for the attainment of good governance in Nigeria:

Since democracy has been found to be well connected with the availability of good governance, and that it is the political class that constitutes stumbling block to its existence in Nigeria, religious leaders, especially Muslims must be ready to generate awareness for citizen engagement in the Muslim brothers and sisters for good governance to be enthroned in Nigeria. For this to sail smoothly, religious leaders should eschew ethical vices like selfishness and greed. The religious followers too are not left out in this direction. 


\section{References}

Adegboruwa, E. (2019, July 23). Advancing the Nigerian democratic outlook through the law (3). Nigerian Tribune, p. 40.

Adegboruwa, E. (2019, July 9). Advancing the Nigerian democratic outlook through the law (1). Nigerian Tribune, p. 40.

Adegboruwa, E. (2019, May 14). Nigeria as a failed state. Nigerian Tribune, p. 40.

Adeleke, G. O. \& Solaru, O. E. (2018). Illusions and dialectics of change: Governance perspective. SAAPADE Journal of Management, Science and Technology, 2 (1), 172185.

Ali, A. Y. (1999). The Holy Quran: Text translation and commentary. Washington DC: Armana-Islamic Centre.

Anyan' Nyango, P. (1988). Political instability and the prospects for democracy in Africa. African Development, 13 (1), p.72.

Diamond, L. (2009). The spirit of democracy: How to make democracies work, Zenith Economic Quarterly. A Publication of Zenith Bank, 4 (1).

Emenuo, F. C. (2015). Democracy, human rights and the rule of law. In: R. Anifowose \& F. Emenuo (eds.) Elements of politics (pp. 141-155). Akoka Yaba: Sam Oroanusi Publications.

Gauba, O. P. (2007). An introduction to political theory. Dehli: Macmillan India Ltd, p. 275.

Jega, A. M. (2007). Democracy, good governance and development in Nigeria. Ibadan: Spectrum Books Ltd.

Mailafia, O. (2019, May 27). How democracies die. Nigerian Tribune, p. 40.

Maulana, M. A. (2006). The manual of Hadith. Lahore: Anguma Ishat Publications.

Mohammad, G. B. (2009). Religion, politics and the Nigerian State: reflections on the experience of the North-West zone. In O. A. Olutayo, \& I. S. Ogundiya (eds.) State and civil society relations in Nigeria (pp. 140-168). Ibadan: Hope Publications Ltd.

Obianyo, N. E. (2009). Reconstructing the state in Africa: Good governance, market reform and virtual governance- The experience of Nigeria. Nigerian Journal of International Affairs. 35 (1), (9-40).

Ogundiya, I. S. (2009). The legitimation mobilisation in Nigeria: A cross-epoch analysis. In: Olutayo, O. A., Ogundiya, I. \& Amzat, J. (Eds.) State and civil society relations in Nigeria (pp. 24-47). Ibadan: Hope Publications Ltd. 
Ojo, E. O. (2009). Mechanisms of national integration in a multi-ethnic federal state: The 'Nigerian experience. Ibadan: John Archers Publisher Ltd, pp. 75 \& 122.

Okoye, I. K. (2013). The church in politics, Report of the Proceedings and Papers of the Divine Commonwealth Conference (DIVCCON), on the theme "Go Forward" (Ex. 14:15), Held at the National Christian Centre, Central Business District, Abuja between Monday 18 to Friday November.

Waziri, F. (2009, May 27). How corruption undermines democracy. Nigerian Compass, pp.46-47. 